\section{THE BISPECIFIC INNATE CELL ENGAGERS AFM13 (CD30/ CD16A) AND AFM24 (EGFR/CD16A) INCREASE THE FRACTION OF TUMOR TARGET-RESPONSIVE NK CELLS AND BOOST SERIAL KILLING}

${ }^{1}$ Chiara Zambarda*, ${ }^{1}$ Karolin Guldevall*, ${ }^{1}$ Chiara Zambarda, ${ }^{1}$ Karolin Guldevall, ${ }^{2}$ Christian Breunig, 'Damien Toullec, 'Jacopo Fontana, ${ }^{2}$ Sheena Pinto, ${ }^{2}$ Jens Pahl, ${ }^{2}$ Susanne Wingert, ${ }^{2}$ Joachim Koch, ${ }^{1}$ Björn Önfelt. ${ }^{1}$ KTH Royal Institute of Technology, Solna, Sweden; ${ }^{2}$ Affimed GmbH, Heidelberg, Germany

Background The use of bispecific natural killer (NK) cell engagers has emerged as a successful strategy for immune cell activation and killing of tumor cells through antibody-dependent cellular cytotoxicity (ADCC). Among these, tetravalent, bispecific innate cell engagers $\left(\mathrm{ICE}^{\circledR}\right)$ with specificity for the activating receptor CD16A selectively triggering innate responses from $\mathrm{NK}$ cells or macrophages represent the most clinically advanced concept. The CD30/CD16A specific ICE ${ }^{\circledR}$ AFM13, has shown efficacy in patients with CD30+ lymphomas as monotherapy ${ }^{1}$ and combination therapy with checkpoint inhibitors ${ }^{2}$ and most recently in combination with adoptive NK cell therapy. ${ }^{3}$ The EGFR/CD16A specific ICE ${ }^{\circledR}$ AFM24, targeting a variety of solid tumors like colorectal, or lung cancer with a unique mode of action independent of EGFR signaling inhibition, is currently evaluated in an ongoing Ph1/2a clinical study.

Methods We used a microchip-based screening with single cell resolution $^{4}$ to elucidate the dynamic responses of individual NK cells towards tumor target cells upon treatment with AFM13 or AFM24.

Results We found that AFM13 and AFM24 mediated potent activation of NK cells, leading to increased responsive cytotoxic NK cells and significantly increased the number of NK cells that exerted engagement with multiple target cells rendering these NK cells serial killers. Strikingly, bispecific ICE $^{\circledR}$ molecules triggered stronger cytotoxic responses compared to monoclonal antibodies. One suggested strategy to boost killing by $\mathrm{NK}$ cells is to use molecular inhibitors or protein constructs that prevent shedding of CD16. ${ }^{5}$ However, previous results have shown that this can lead to impaired detachment from target cells, reducing the capacity for an individual NK cell to form serial contacts to target cells. ${ }^{6}$ We observed that the elevated NK cell killing induced by $\mathrm{ICE}^{\circledR}$ molecules was largely conserved when cells were treated with the shedding inhibitor Batimastat. Analysis of the functional dynamics of NK cells revealed that inhibition of CD16 shedding prevented NK cell detachment from target cells, resulting in cell cluster formation. This might strongly impact targeting of distant tumor cells by an individual NK cell thus limiting its antitumoral activity.

Conclusions In conclusion, we show that both AFM13 and AFM24 increase the fraction of tumor-target responsive NK cells and boost serial killing of target cells by individual NK cells. Based on these data, ICE ${ }^{\circledR}$ molecules can be characterized as potent anti-tumoral agents leveraging the enormous potential of NK cells while maintaining crucial features of NK cell biology.

Acknowledgements We thank members of the Önfelt lab for their valuable help and feedback.

\section{REFERENCES}

1. Sawas A, Elgedawe H, Vlad G, Lipschitz M, Chen P-H, Rodig SJ, et al. Clinical and biological evaluation of the novel CD30/CD16A tetravalent bispecific antibody (AFM13) in relapsed or refractory CD30-positive lymphoma with cutaneous presentation: a biomarker phase Ib/lla study (NCT03192202). Blood 2018;132(Supplement 1):2908-2908.
2. Bartlett NL, Herrera AF, Domingo-Domenech E, Mehta A, Forero-Torres A, GarciaSanz $R$, et al. A phase 1b study of AFM13 in combination with pembrolizumab in patients with relapsed or refractory Hodgkin lymphoma. Blood 2020. Blood 2020:136(21):2401-2409.

3. Kerbauy LN, Marin ND, Kaplan M, Banerjee PP, Berrien-Elliott MM, Becker-Hapak $M$, et al. Combining AFM13, a bispecific CD30/CD16 antibody, with cytokine-activated blood and cord blood-derived NK cells facilitates CAR-like responses against CD30 + malignancies. Clin Cancer Res Epub 2021.

4. Guldevall K, Brandt L, Forslund E, Olofsson K, Frisk TW, Olofsson PE, et al. Microchip screening platform for single cell assessment of NK cell cytotoxicity. Front Immunol 2016;7:119.

5. Romee R, Foley B, Lenvik T, Wang Y, Zhang B, Ankarlo D, et al. NK cell CD16 surface expression and function is regulated by a disintegrin and metalloprotease17 (ADAM17). Blood 2013;121(18):3599-608.

6. Srpan K, Ambrose A, Karampatzakis A, Saeed M, Cartwright ANR, Guldevall K, et al. Shedding of CD16 disassembles the NK cell immune synapse and boosts serial engagement of target cells. J Cell Biol 2018;217(9):3267-83.

Ethics Approval This work was performed with NK cells from healthy anonymous blood donors, which requires no ethical permit according to local regulations.

http://dx.doi.org/10.1136/jitc-2021-SITC2021.894 